\title{
Analisis Pendapatan Usahatani Sawi Pola Kemitraan dan Non Mitra di Kecamatan Megamendung Kabupaten Bogor Jawa Barat
}

\section{(Analysis of Income of Mustard Green Farming in Partnership and Non-Partner Patterns in Megamendung Sub-District, Bogor Regency, West Java)}

\author{
Annisa Fitri $\left.{ }^{*}\right)$, Harianto ${ }^{* *}$, dan Ratna Winandi Asmarantaka ${ }^{* * *)}$ \\ *) Politeknik Negeri Lampung \\ **) Fakultas Ekonomi dan Manajemen, Institut Pertanian Bogor \\ 1) Email : annisafitrihasibuan92@gmail.com
}

\begin{abstract}
Partnership is one of the institutions that plays an important role in agricultural development in Indonesia. Contracts in partnerships result in differences in production, productivity, and cultivation techniques. Farmers who have not been able to allocate optimally production factors in their farming production processes will influence the production costs and farmers' income. This study aims to identify factors that influence farmers participating in partnerships, the effect of partnerships on the efficiency of mustard farming, and the factors that influence the inefficiency of mustard farming. This study uses cross section data from 70 samples of mustard farmers, consisting of 35 partner farmers and 35 non-partner farmers. The method used is cost analysis and income analysis. The results showed that the average income of partner farmers for cash costs amounted to Rp 20,932,943 and profits at a total cost of $R p$ 12,828,443. In non-partner farmers, income from cash costs amounted to $R p .22,118,483$ and revenues from total costs amounted to Rp. 14,492,164. Partner farmer income is lower than non-partner farmers. With participation participating partnering to reduce income because of different input and output prices between partner farmers and non-partner farmers.
\end{abstract}

Keywords: Partnership, farming income, green mustard

Diterima: 20 Agustus 2018. / Disetujui: 9 Mei 2019

\section{PENDAHULUAN}

Hortikultura merupakan salah satu sub sektor pertanian yang strategis dan penting, karena peranannya sebagai pola pangan harapan. Komoditas hortikultura khususnya sayuran berperan penting untuk keseimbangan pangan yang dikonsumsi, sehingga harus tersedia setiap saat dalam jumlah yang cukup, mutu yang baik, aman dikonsumsi, harga terjangkau, serta dapat di akses oleh lapisan 
masyarakat (Direktorat Jenderal Tanaman Hortikultura, 2016). Salah satu komoditi sayuran diminati oleh masyarakat adalah sawi. Tanaman sawi mengandung mineral, vitamin, protein, dan kalori. Bagian sawi yang dimanfaatkan daun atau bunganya sebagai bahan pangan (sayuran), baik segar maupun diolah. Oleh karena itu, tanaman sawi menjadi komoditas sayuran yang berpotensi dan prospektif di usahakan di Indonesia.

Kemitraan merupakan salah satu kelembagaan berperan penting dalam pembangunan pertanian di Indonesia. Kemitraan untuk komoditi sayuran banyak berkembang di daerah sentra sayuran seperti Jawa Barat. Berdasarkan data (BPS, 2015) Jawa barat merupakan provinsi dengan jumlah produksi (210 493 ton), luas panen (14 105 ha), dan produktivitas (14.92 ton/ha) sayuran sawi tertinggi di Indonesia. Produktivitas sawi di Jawa Barat tertinggi pertama di Indonesia, namun masih terdapat Kabupaten di Jawa Barat yang produktivitas sawi masih rendah yaitu Kabupaten Bogor. Berdasarkan (BPS, 2016) produktivitas sawi Kabupaten Bogor sebesar 4.79 ton/ha masih lebih rendah jika dibandingkan dengan produktivitas di Jawa Barat sebesar 14.92 ton/ha. Pelaksanaan kemitraan sistem kontrak produksi dan pemasaran dapat dilihat di Kabupaten Bogor khususnya di Kecamatan Megamendung. Kegiatan kemitraan yang terjalin antara perusahaan PT Sayuran Siap Saji di Kecamatan Megamendung dan petani sawi berupa akses pasar dan bimbingan teknis, sehingga menjadi faktor pendorong untuk meningkatkan produksi usahatani sawi.

Penelitian (Milliondry, 2014) menemukan bahwa produktivitas sawi produktivitas petani mitra februari 2012 sebesar 10.82 ton per hektar lebih rendah dari petani non mitra 11.78 ton per hektar. Hasil tersebut kontradiktif dengan teori dan berbagai kajian empirik yang menyatakan bahwa kemitraan solusi untuk meningkatkan produktivitas (Hafsah JM, 2000); dan (Champika \& Abeywickrama, 2015). Petani yang belum mampu mengalokasikan secara optimal semua faktor produksi yang ada dalam proses produksi usahataninya akan berpengaruh terhadap biaya produksi dan pendapatan petani. Pendapatan yang diperoleh petani akan berbeda-beda sesuai dengan tingkat kemampuan petani dalam mengalokasikan faktor-faktor yang dimilikinya. Dengan demikian perlu dilakukan penelitian bagaimana pendapatan usahatani sawi petani mitra dan petani non mitra di Kecamatan Megamemndung Kabupaten Bogor?

\section{METODE PENELITIAN}

Penelitian ini dilakukan di Kecamatan Megamendung Kabupaten Bogor. Pemilihan lokasi dilakukan secara purposive dengan pertimbangan bahwa 1) Produktivitas tertinggi di Kabupaten Bogor, 2) Kecamatan Megamendung memiliki akses ke pasar lebih mudah. Penelitian dilaksanakan Maret - Mei 2017.

Penelitian ini menggunakan data primer melalui wawancara kepada petani dengan panduan kuesioner. Jenis data yang digunakan adalah data cross section. Berdasarkan data dari penyuluh perusahaan jumlah petani sawi mitra PT Sayuran Siap Saji sebanyak 35 petani, sehingga 35 petani tersebut dijadikan sampel didalam penelitian ini. Pengambilan sampel untuk petani non mitra dengan cara snowball sebanyak 35 petani. Total petani yang dijadikan sampel sebanyak 70 petani.

\section{Analisis Biaya}

Biaya adalah seluruh korbanan yang digunakan untuk menghasilkan produksi yang terdiri dari biaya tetap (fixed Cost) (sewa lahan, biaya penyusutan, perbaikan alat-alat, bunga bank,biaya mesin), 
Fitri A : Analisis Pendapatan Usahatani Sawi Pola Kemitraan dan Non Mitra di Kecamatan Megamendung Kabupaten Bogor Jawa Barat

dan biaya tidak tetap (Variabel Cost) (benih, pestisida, pupuk organik, pupuk kimia,tenaga kerja luar). Besarnya pendapatan yang diperoleh dapat dihitung dengan menghitung biaya keseluruhan yang dikorbankan terlebih dahulu dengan menggunakan rumus.

\section{$\mathbf{T C}=\mathbf{T F C}+\mathbf{T V C}$}

Dimana :

TC : Total Cost (Total Biaya)

TFC : Total Fixed Cost (Jumlah Biaya Tetap)

TVC : Total Variable Cost (Jumlah Biaya Tidak Tetap)

\section{Analisis Penerimaan}

Penerimaan (revenue) usahatani adalah semua nilai produk yang dihasilkan dari suatu usahatani dalam satu periode tertentu, satu musim tanam atau dalam satu tahun kegiatan usahatani. Menurut (Suratiyah K., 2009) formula menghitung penerimaan adalah sebagai berikut:

\section{TR = Py X Y}

Dimana

TR : Total Revenue (total penerimaan)

Y : Jumlah Produk (Kg)

Py : Harga Jual Per satuan Luas $(\mathrm{Rp} / \mathrm{Kg})$

\section{Analisis Pendapatan}

Pendapatan adalah selisih antara penerimaan semua biaya yang dikeluarkan dan diukur dalam satuan rupiah $(\mathrm{Rp} / \mathrm{musim})$. Adapun rumusnya adalah sebagai berikut:

$$
\boldsymbol{\pi}=\mathbf{T R}-\mathbf{T C}
$$

Dimana :

$\pi=$ Pendapatan (keuntungan)

$\mathrm{TR}=$ Total Revenue (total penerimaan)

$\mathrm{TC}=$ Total Cost (biaya total)

\section{Analisis Rasio Revenue-Cost}

Dihitung berdasarkan perbandingan antara nilai input dengan nilai produk (output) pada saat akhir produksi. Setelah keuntungan usahatani masing-masing produk sudah diketahui dapat menggunakan analisis RC ratio Return Cost Ratio, yaitu dengan membandingkan antara penerimaan dengan biaya produksi dan dapat diperoleh dengan menggunakan rumus :

$$
\mathrm{RC} \text { rasio }=\frac{}{\text { Jumlah Penerimaan }(\mathrm{Rp})}
$$

Bila nilai RC rasio > 1 maka usahatani tersebut sudah layak

Bila niali RC rasio $<1$ maka usahatani tersebut tidak layak

Bila niali RC rasio = 1 maka nilai produksi dengan biaya adalah sama besar atau titik impas. 


\section{HASIL DAN PEMBAHASAN}

Pendapatan usahatani terdiri atas pendapatan terhadap biaya tunai dan keuntungan terhadap biaya total.Tabel 1 dapat diketahui pendapatan yang diperoleh petani mitra dan petani non mitra pada lahan 1 hektar terbagi atas biaya tunai dan biaya total (biaya non tunai dan biaya tunai). Pendapatan rata-rata petani mitra terhadap biaya tunai sebesar Rp 20932943 dan keuntungan atas biaya total Rp 12828 443. Pada Petani non mitra pendapatan atas biaya tunai sebesar Rp 22118483 dan pendapatan atas biaya total sebesar Rp 14492164.

Berdasarkan Tabel 1 analisis biaya dihitung untuk satu kali periode produksi ( \pm 40 hari) yang dimulai dari persiapan untuk berproduksi, proses produksi, hingga pemanenan. Komponen penggunaan biaya terbesar pada usahatani sawi adalah tenaga kerja luar keluarga. Rata-rata penggunaan tenaga kerja luar keluarga untuk lahan 1 hektar petani mitra 168.22 HOK dengan harga Rp 41 191, sehinnga biaya tenaga kerja luar keluarga sebesar Rp 6929059 atau sebesar 35.31 persen dari biaya total. Penggunaan tenaga kerja luar keluarga petani non mitra rata-rata untuk 1 hektar 121.35 HOK dengan harga Rp 37 142, sehinnga biaya tenaga kerja luar keluarga sebesar Rp 4507059 atau sebesar 25.96 persen dari biaya total. Perbedaan harga rata-rata tenaga kerja petani mitra dan non mitra di sebabkan oleh banyaknya jam kerja dalam sehari. Rata-rata petani mitra bekerja dari pukul 08.00 hingga pukul 16.00 sementara petani non mitra rata-rata bekerja dari pukul 07.00 hingga 12.00 , menyebabkan perbedaan upah. Usahatani sawi lebih banyak menggunakan tenaga kerja manusia (intensive labor) terutama untuk kegiatan pengolahan lahan, penanaman, penyiangan, dan pemanenan. Berdasarkan temuan ini diharapkan adanya penerapan teknologi yang murah yang dapat mengurangi tenaga kerja manusia, sehingga dapat mengurangi biaya usahatani dan meningkatkan keuntungan.

Komponen biaya tebesar kedua petani mitra adalah sewa lahan. Harga lahan untuk 1 hektar rata-rata sebesar Rp 5842857 atau sebesar 29.78. Petani mitra dan petani nonmitra rata-rata untuk satu hektar lahan sebesar Rp 5957143 atau sebesar 34.31 persen. Harga lahan di lokasi penelitian berkisar dari harga Rp 3000000 hingga Rp 10000 000. Perbedaan harga lahan disebabkan oleh kondisi lahan semakin dekat lahan dengan sumber air dan angkutan mudah masuk, harga sewa lahan semakin mahal.

Dari Tabel 1 biaya tunai untuk lahan 1 hektar pada satu musim tanam petani mitra sebesar Rp 11518816 dan petani non mitra sebesar Rp 9737 996. Biaya total pada petani mitra sebesar Rp 19 623316 dan petani non mitra sebesar Rp 17364 314. Berdasarkan analisis biaya petani mitra lebih tinggi dibandingkan dengan petani non mitra, hal ini dikarenakan pada petani mitra harus memenuhi syarat-syarat yang harus dipenuhi seperti daun harus berwarna hijau dan segar, tidak boleh ada bercak dan tidak boleh layu pada daun, dan daun yang diterima tidak banyak bolong. Dengan memperhatikan syarat-syarat yang harus dipenuhi, maka petani mitra membutuhkan tambahan input yang lebih banyak, sehingga sawi dapat diterima oleh PT Sayuran Siap Saji.

Tabel 1 Analisis usahatani sawi pada satu musim tanam dalam 1 ha petani mitra dan petani non mitra

\begin{tabular}{cccccccc}
\hline \multirow{2}{*}{ Uraian } & \multicolumn{3}{c}{ Mitra } & \multicolumn{3}{c}{ Non mitra } \\
\cline { 2 - 4 } & Harga & Nilai & $\begin{array}{c}\text { Persen } \\
(\%)\end{array}$ & Jumlah & Harga & Nilai & $\begin{array}{c}\text { Persen } \\
(\%)\end{array}$ \\
A. Penerimaan & & & & & &
\end{tabular}


Fitri A : Analisis Pendapatan Usahatani Sawi Pola Kemitraan dan Non Mitra di Kecamatan Megamendung Kabupaten Bogor Jawa Barat

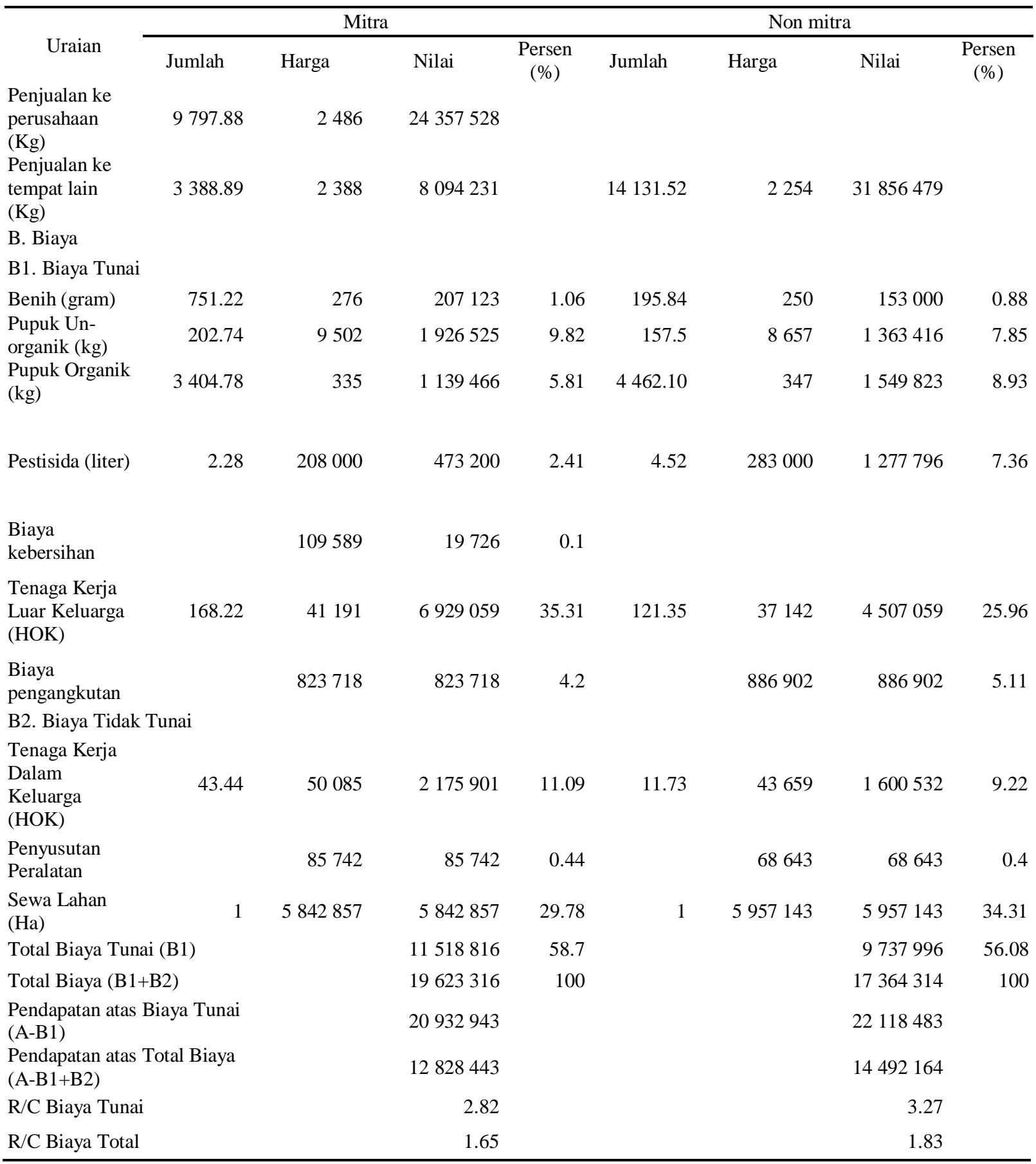

Berdasarkan Tabel 1 penerimaan petani mitra yang berasal dari PT Sayuran Siap Saji sebesar Rp 24357528 dan penerimaan dari penjualan ke tempat lain sebesar Rp 8094 231, sehingga total penerimaan sebesar Rp 32451 759. Penerimaan petani non mitra sebesar Rp 31856 479. Penerimaan petani mitra apabila hanya memperhitungkan menjual ke perusahaan PT Sayuran Siap Saji lebih rendah apabila dibandingkan dengan petani non mitra dikarenakan adanya pemotongan 20 persen oleh pihak perusahaan. Pemotongan 20 persen ini merupakan sayuran yang kualitasnya tidak sesuai kesepakatan dan bagian sayur yang tidak ikut dikemas. Bagian sayur ini khususnya pada sawi seperti bonggol sawi dan bagian ujung daun sawi. 
Analisis $\mathrm{R} / \mathrm{C}$ ratio, nilai $\mathrm{R} / \mathrm{C}$ mengindikasikan suatu usahatani layak atau tidak layak dilakukan. Nilai R/C pada petani mitra bernilai 2.82 atas biaya tunai dan 1.65 atas biaya total. Hal ini berarti setiap biaya yang dikeluarkan petani mitra sebesar Rp 1 akan menghasilkan penerimaan sebesar 2.82 dan 1.65. Sedangkan nilai R/C rasio pada petani non mitra sebesar 3.27 atas biaya tunai dan 1.83 atas biaya total. Artinya biaya yang dikeluarkan petani non mitra sebesar Rp 1 akan menghasilkan penerimaan 3.27 dan 1.83. Hasil ini membuktikan bahwa usahatani sawi petani mitra dan petani non mitra layak untuk diusahakan oleh petani-petani yang berada di daerah penelitian.

\section{KESIMPULAN DAN SARAN}

\section{Kesimpulan}

Pendapatan petani mitra lebih rendah dibandingkan petani non mitra. Dengan partisipasi berpartisipasi bermitra menurunkan pendapatan karena harga input dan output yang berbeda antara petani mitra dan petani non mitra.

\section{Saran}

Perusahaan sebaiknya mempertimbangkan besarnya pemotongan hasil panen pada petani mitra, kaena berdampak pada penerimaan yang diterima petani mitra lebih rendah dari petani non mitra. Hal ini akan mendorong petani mitra untuk menjual hasil panen ke tempat lain.

\section{DAFTAR PUSTAKA}

BPS. (2015). Statistik Indonesia. Jakarta: Badan Pusat Statistik.

BPS. (2016). Jawa Barat Dalam Angka. Jawa Barat (ID): Badan Pusat Statistik.

Champika, P. A. J., \& Abeywickrama, L. M. (2015). An evaluation of maize contract farming system in Sri Lanka: adoption, problems and future prospects. Tropical Agricultural Research, 26(1), 62. https://doi.org/10.4038/tar.v26i1.8072

Direktorat Jenderal Tanaman Hortikultura. (2016). Data produksi hortikultura Indonesia Tahun 2011 2015. Jakarta.

Hafsah JM. (2000). Kemitraan Usaha, Konsep dan Strategi. Jakarta (ID): PT Penebar Swadaya.

Milliondry, H. D. (2014). Perbandingan usahatani caisin petani mitra dan non mitra di kecamatan megamendung skripsi hydro dita milliondry, 1-60. Retrieved from file:///C:/Users/Hp/Documents/SKRIPSI/jurnal indo/H14hdm.pdf

Suratiyah K. (2009). Ilmu Usahatani. Jakarta (ID): PT Penebar Swadaya. 